\title{
From Nabokov's Amerussia to Mallarmé's Donje te zankoriv: Vladimir Nabokov at the crossroads of languages
}

Julie Loison-Charles

\section{(2) OpenEdition \\ Journals}

Electronic version

URL: http://journals.openedition.org/esa/765

DOI: $10.4000 /$ esa.765

ISSN: 2650-2623

Publisher

Société de stylistique anglaise

Printed version

Date of publication: 1 December 2016

Number of pages: 121-135

ISBN: 978-2-36442-075-5

ISSN: $2116-1747$

Electronic reference

Julie Loison-Charles, «From Nabokov's Amerussia to Mallarmé's Donje te zankoriv: Vladimir Nabokov at the crossroads of languages », Études de stylistique anglaise [Online], $10 \mid 2016$, Online since 19

February 2019, connection on 01 May 2019. URL : http://journals.openedition.org/esa/765 ; DOI : 10.4000/esa.765 


\title{
From Nabokov's Amerussia to Mallarmé's Donje te zankoriv: Vladimir Nabokov at the crossroads of languages
}

\author{
Julie LOISON-CHARLES \\ Université Charles de Gaulle - Lille 3 \\ CECILLE, EA1074
}

\begin{abstract}
Vladimir Nabokov wrote nine novels in Russian and nine in English (one is incomplete). This striking symmetry begs the question of his identity: was he a Russian author who then became an American novelist or was he both, that is, a Russian-American writer? In my opinion, Nabokov's multilingualism is his most crucial feature as code-switching is at the heart of his English style. Therefore, he can be best characterized as a cosmopolitan writer. According to sociologist Dharwadker $(2011,140)$,

A cosmopolitan is a citizen of the world because she has the capacity to be at home in different societies; but to be so does not necessarily mean that she mixes different cultures. Rather, it means that she is able to switch back and forth between places and cultures, so that when she is at one location, she changes over to the codes required there. This entails that a cosmopolitan differentiate among her cultural locations; and that she practice what linguists and anthropologists call code-switching (which occurs in bilingualism and multilingualism) rather than code-mixing (which occurs in linguistic creolization).
\end{abstract}

In Nabokov's novels in English, the juxtaposition of languages which is at work in code-switching is predominant, but, occasionally, he indulges in hybridity. He does so by mixing tongues, for example in bilingual portmanteaux words, or by merging the syntaxes of two languages. In those cases, confluence makes him resemble, linguistically and stylistically speaking, Creole writers: 
FROM NABOKOV'S AMERUSSIA TO MALLARMÉ'S DONJE TE ZANKORIV:

VLADIMIR NABOKOV AT THE CROSSROADS OF LANGUAGES

In contrast, the hybrid or Creole subject inhabits a single culture of her own, which emerges in the intermingling of two prior cultures; she mixes (and mixes up) their codes, and is no longer fully at home in either in its unmixed form. (Dharwadker 2011, 140)

This fusion of languages which is sometimes used by Nabokov implies his prose is creolized, in the sense of Glissant's philosophy:

J'appelle ici créole - contrairement peut-être aux règles - une langue dont le lexique et la syntaxe appartiennent à deux masses linguistiques hétérogènes : le créole est un compromis. (Glissant 1990, 132)

This hybridization of tongues is manifest in four of Nabokov's novels.

In Lolita and Ada, the two main novels where sexuality is central to the plot, Nabokov creates two macaronic tongues which are closely associated with eroticism but which are only used once in each novel. In two other novels, Bend Sinister and Pale Fire, Nabokov invented forged languages which are used extensively throughout the novels: in Bend Sinister, the "vernacular" is defined by Nabokov as "a mongrel blend of Slavic and Germanic" (Nabokov 1947, 166); in Pale Fire, "Zemblan" is the creolized language of an exile torn between his two identities, the character's repression breaking through in the madness played out across his tongue.

In all cases, forged languages are not just proof of the multilingual author's creativity. They actually play a part in the plot or in the relationship that is established between the reader and the text. The functions that can be assigned to hybridized languages are consistent with those of code-switching and underline the systemic value of foreign words in Nabokov's oeuvre.

\section{Macaronic tongues and eroticism in Lolita and Ada}

The expression "macaronic tongue" was supposedly forged by sixteenth-century poet Teofilo Folengo. This term is now used quite loosely to refer to any hybrid tongue mixing a vulgar language with Latin. More specifically speaking, Fausta Garavini (1982, 40) argues that a true macaronic tongue implies that Latin endings be grafted on words from a vulgar tongue, such as English or French, with the purpose of creating a comic result. In the following two examples, Latin is not always used but 
as it is predominant and as humor is clearly intended, I will use the term "macaronic" in its broad sense. Therefore, Nabokov's hybrid tongues rely on vocabulary, when they merge English and French words for example, but also on syntax when they resort to Latin endings, thus mixing English and Latin syntaxes. In both cases, hybrid languages are used when a fusion of tongues is at play, in a linguistic sense but also sexually speaking: languages are hybridized when tongues and bodies are entangled.

\section{Lolita, from French kiss to macaronic tongue}

In Lolita, Humbert dreams at length of Lolita's body. When the nymphet's mother finally dies, Humbert goes to fetch Lolita from summer camp. In their motel, he plans on giving her sleeping pills in order to abuse her in her sleep but the young girl is the one who makes the first move. Humbert is so startled by her boldness that he loses his control on language:

\footnotetext{
"What's the katter with misses?" I muttered (word-control gone) into her hair.

"If you must know," she said, "you do it the wrong way."

"Show, wight ray."

"All in good time," responded the spoonerette.

Seva ascendes, pulsata, brulans, kitzelans, dementissima. Elevator clatterans, pausa, clatterans, populus in corridoro. Hanc nisi mors mihi adimet nemo! Juncea puellula, jo pensavo fondissime, nobserva nihil quidquam; but, of course, in another moment I might have committed some dreadful blunder; fortunately, she returned to the treasure box. (Nabokov 1955, 113)
}

Humbert starts losing control over his language in spoonerisms that are rather easy to reconstruct: "what's the katter with misses", "show wight ray". The macaronic tongue that then appears in his prose is quite transparent in its first half: Humbert is describing what he feels or hears. Indeed, the reader can recognize one English word without alteration, "elevator", and several others with Latin endings, such as "puls/ata", "clatter/ans", "paus/a", or "corridor/o". She can also recognize French words behind "Seva ascendes (...) brul/ans" or German words in "kitzelans", that is "kitzel" (tickle) or "kitzler" (clitoris). And then, some apparently Latin words are quite transparent, such as "dementissima" or "populus". The second part is harder to decipher.

Indeed, there are only Latin words in this paragraph, but the endings are all faulty, as opposed to the first half of the paragraph. The reader who does not speak Latin cannot have any access to meaning but 
FROM NABOKOV'S AMERUSSIA TO MALLARMÉ'S DONJE TE ZANKORIV:

VLADIMIR NABOKOV AT THE CROSSROADS OF LANGUAGES

she understands that strong emotions are being expressed thanks to the exclamation mark and, more importantly, she understands that Humbert is so overwhelmed that he cannot speak properly. When the little girl leaves him ("she returned to the treasure box"), he manages to retrieve his mastery over English.

\section{Ada or Ardor: rewriting the Kama Sutra in Kapuskan}

Another example of macaronic tongue can be found in Ada, which is Nabokov's most multilingual novel. In $A d a$, the geography of the planet, Antiterra, is different from our own insofar as countries in our own world exist in combined forms, the most striking example being Amerussia. Linguistically speaking, languages that are familiar to the reader are often mixed up to produce Antiterrian tongues. In the following passage, Ada and Van, who are brother and sister, but also lovers, are looking for books which could help them find new positions and a way to avoid pregnancy:

Still more amusing was the "message" of a Canadian social worker, Mme de Réan-Fichini, who published her treatise, On Contraceptive Devices, in Kapuskan patois (to spare the blushes of Estotians and United Statians; while instructing hardier fellow-workers in her special field). "Sole sura metoda," she wrote, "por decevor natura, est por un strong-guy de continocontino-contino jusque le plesir brimz; et lors, a lultima instanta, svitchera a l'altra gropa [groove]; ma perquoi una femme ardora andor ponderosa ne se retorna kvik enof, la transita e facilitata per positio torovago"; and that term an appended glossary explained in blunt English as "the posture generally adopted in rural communities by all classes, beginning by the country gentry and ending with the lowliest farm animals throughout the United Americas from Patagony to Gasp." Ergo, concluded Van, our missionary goes up in smoke. (Nabokov 1969, 110)

In this Kapuskan patois which seems to be Latin-based, one can actually recognize French and English as the main components. Indeed, the only words that are not hybridized are the English "strong-guy" and the French "femme": this linguistic couple goes to confirm that each gender is associated with a language and that, during sexual intercourse, code-mixing is a metaphor for sex. Then, several English words are disguised, but not well enough to prevent recognition: behind "decevor", "brimz", "svitchera" and " $k v i k$ enof", it is quite easy to recognize "deceive", "brim", "switch" and "quick enough". Likewise, "le plesir", "perquoi", "ne se retorna" and "facilitata" are easy to decipher for a French speaker. The only translated word is "gropa", where one can read the tactile verb "to grope". Its inscription between square brackets 
[groove] and without italics draws the reader's attention to a very explicit English word.

The purpose is clearly recreational: after deciphering this patois without much difficulty, the English-speaking reader is rewarded with the fun of reading a sexually explicit description of contraception. It is clear that Nabokov intends for the reader to be able to decipher this patois. Indeed, if one looks at the French translation of the novel, in which Nabokov played an important part, one can notice that words that were too English were replaced by pseudo-Latin words that are easier for a French speaker to understand:

Jusque le plesir brimz; et lors, a lultima instanta, svitchera a l'altra gropa [groove]; ma perquoi una femme ardora andor ponderosa ne se retorna kvik enof, la transita e facilitata per positio torovago. (Nabokov 1969, 110)

Jusque le plesir brase; et lors, à lultima instanta devia à l'altro fenta; ma perquoi una femme ardor et ponderosa ne se retorna satis presto, la transita e facilitata per positio torovago. (Nabokov 1975, 116)

In Lolita and Ada, the two hybrid languages are clearly sexually connoted: thus, they work hand-in-hand with the plot and, at the same time, they play a recreational part for the reader-decipherer. The two forged languages that Nabokov uses extensively in Bend Sinister and Pale Fire have other additional functions: they help reveal the plot or are symptomatic of a character's pathology.

\section{Bend Sinister: a dystopian world and its vernacular}

\section{The German-Russian vernacular}

Bend Sinister is the second novel that Nabokov wrote in English. The story takes place in an invented country whose name is never given. It is ruled by a dictator, Paduk, and the language that is spoken is called "the vernacular". This forged language is a mix of German and Russian. Nabokov did not choose these two languages at random, as he explained in his introduction:

There can be distinguished, no doubt, certain reflections in the glass directly caused by the idiotic and despicable regimes that we all know and that have brushed against me in the course of my life: worlds of tyranny and torture, of Fascists and Bolshevists, of Philistine thinkers and jackbooted baboons. No doubt, too, without those infamous models before me I could not have interlarded this fantasy with bits of Lenin's speeches, and a chunk 
FROM NABOKOV'S AMERUSSIA TO MALLARMÉ'S DONJE TE ZANKORIV:

VLADIMIR NABOKOV AT THE CROSSROADS OF LANGUAGES

of the Soviet constitution, and gobs of Nazist pseudo-efficiency. (Nabokov $1947,164)$

Nazism and Bolshevism did more than brush against Nabokov as they had a tremendous impact on his life: Nabokov had to flee Russia in 1917 when the Bolshevists took over the country and his family lost everything they had there. Nabokov then lived in exile in Europe, mainly in Germany, until he was forced to escape again in 1940: his wife and son were Jewish and going to America was a matter of life-or-death for them. The linguistic blend of German and Russian is therefore politically motivated as it results in the language of a tyrannical state.

Those two languages are sometimes used in their unmixed form. Thus, when the main character Krug meets Paduk, the dictator, he is asked to give a speech. The Russian words that are used echo the Soviet tone of the text:

"Ladies and gentlemen! Citizens, soldiers, wives and mothers! Brothers and sisters! The revolution has brought to the fore problems [zadachi] of unusual difficulty, of colossal importance, of world-wide scope [mirovovo mashtaba]. Our leader has resorted to most resolute revolutionary measures calculated to arouse the unbounded heroism of the oppressed and exploited masses." (Nabokov 1947, 287)

If Russian is used in the political speeches of the tyrannical regime, some of Paduk's followers use German, as in the following passage: "I did not mean what you mean, you bad boy. The Professor will think Gott weiss was." (Nabokov 1947, 266) Here the proximity between "Gott" and "God" will help the monolingual reader to guess that the foreign segment probably means "God knows what", even if she cannot be sure whether it is written in German or in the vernacular.

In Bend Sinister, the use of German and Russian, in their mixed or unmixed forms, has two functions: it has an illustrative value and gives a bit of "couleur locale", thus asserting the localization in a given place, albeit imaginary; it also endows the novel with connotations usually associated with the languages used, and therefore has a connotative function. In Nabokov's novels, one also finds a revealing function in foreign (or invented) words: foreign words are often used as symptoms or clues to hint at the way the plot will unravel. Bend Sinister is no exception.

In the following passage, the main character, Adam Krug, tries to find a way to get his friends out of prison and asks a man to help him. However, considering the German-Russian words used by this supposed 
saviour, one might guess that this man is actually working for the dictator and that he will not help Krug in the end:

"And there is no way to get them out of there?" asked Krug.

"Out of where? Oh, I see. No. My organization is of a different type. We call it fruntgenz [frontier geese] in our professional jargon, not turmbrokhen [prison breakers]. So you are willing to pay me what I ask?” (Nabokov 1947, 312)

Although a native German speaker might read the first foreign word as a word in German dialect, there is no way she would do so for the second one. The first word seems to be a hybrid between two German words: "Fruntgenz" is translated by "frontier geese" but a German speaker will see "genz" as a kind of portmanteau word mixing "gänse" (geese) and "grenze" (frontier). If this portmanteau word means "frontier geese", it implies that "frunt" is just optional. However, a French or English speaker could see it as an altered truncation of the French "frontière" or the English "frontier". This vernacular word is therefore a mix between German and another European language.

The word "turmbrokhen" is even more interesting. The first half, "turm", is very close to the Russian word "tjurma" (prison), as suggested by the translation between brackets. But a German speaker would see in it the German word for "castle" ("turm"), which is another place where one can keep convicts. The second half of the word, "brokhen", encompasses the English "broken" (close to the translation "breakers"), with a Russian $/ \mathrm{kh} /$ in its middle, which also evokes the German word for "break", "ausbrechen".

Obviously, recognizing those words as vernacular implies that the reader can recognize what language is being used, be it Russian or German, let alone vernacular. It is almost impossible for a monolingual reader to decipher the foreign words and she is left to her own devices. Therefore, the vernacular gives rise to hesitation, when it comes to guessing what language is used or more generally when it comes to understanding what it all means. As it engenders interpretative hesitation, Nabokov's vernacular might be called a "fantastic language", if one follows Sorlin's terminology:

Les langues fantastiques [...] se situent toujours dans un entre-deux. En perpétuel mouvement, ces langues ne peuvent s'immobiliser ou se fixer. De la même façon que dans le genre fantastique selon Todorov, on tue le fantastique dès que la perception des choses devient claire, dans les dystopies linguistiques, si le sens se fait clair et univoque, on condamne la 
FROM NABOKOV'S AMERUSSIA TO MALLARMÉ'S DONJE TE ZANKORIV:

VLADIMIR NABOKOV AT THE CROSSROADS OF LANGUAGES

langue fantastique, car “c'est l'hésitation qui lui donne vie”. (Sorlin 2010, 16)

Bend Sinister is indeed a dystopia and Nabokov's hybrid tongue, based on two politically motivated languages, is in that sense a fantastic and dystopian language.

\section{Fighting tyranny with creativity}

Sometimes, the hybridity of the vernacular is used as a playful way to fight the oppression of the dictatorship. Indeed, on two occasions, the vernacular relies on French to evoke poetry:

"Prakhtata meta?" poor Dr Azureus cried to the very quiet assembly.

"Prakhtata tuen vadust, mohen kern! Profsar Krug malarma ne donje... Prakhtata!" (Nabokov 1947, 213)

"I am really sorry," said Krug, "but I have to pass. Donje te zankoriv [do please excuse me]." (Nabokov 1947, 216)

In the first quote, no translation is given but one may notice that the same word, Prakhtata, is repeated three times. And then, "Profsar Krug" is quite transparent and must refer to the main character Krug, who is indeed a professor. Next to it, one may recognize a reference to French poet Mallarmé. In his introduction, Nabokov confirms this poetic hint:

Stéphane Mallarmé has left three or four immortal bagatelles, and among these is L'Après-midi d'un Faune (first drafted in 1865). Krug is haunted by a passage from this voluptuous eclogue where the faun accuses the nymph of disengaging herself from his embrace "sans pitié du sanglot dont j'étais encore ivre" ("spurning the spasm with which I still was drunk"). (Nabokov 1947, 167-168)

This hint makes the two quotes clearer and one can see in "Donje", and then "Donje te zankoriv", a playful echo to Mallarmé. Therefore, hybridity can also be a poetic code for the reader to decipher, just like the macaronic tongues in Lolita and Ada, but it also induces complicity between the reader-decipherer and the tyrannical author (Couturier, 1993) or between the reader and Krug against the dictator.

\section{Pale Fire: Zemblan as the return of the linguistically repressed}

Pale Fire is composed of several elements: first, a poem by John Shade, who was supposed to write one thousand lines on the topic of his 
daughter's suicide but got killed before he wrote the last line; it is preceded by an introduction and followed by a very long commentary and index which were all written by Kinbote, a neighbor of John Shade's who was next to him when he was shot. But far from commenting on the poem as a good, serious scholar, Kinbote takes every possible word in the poem as an excuse to talk about himself, about his life, about his tragedy. $\mathrm{He}$ contends that he is the King of a country called Zembla, that oppressors want to kill him, even in his exile, and that Kinbote was the real target of the shot that accidentally killed the poet John Shade. His story could make us think that Pale Fire is yet another dystopia but it becomes clear very quickly that the commentator is mad. This means that his language, Zemblan, is fantastic only insofar as it stems from his tormented imagination.

\section{The maddening pain of exile}

The name Kinbote is actually an almost perfect anagram of Botkin, a Russian professor in the university where Kinbote and Shade teach. But Kinbote keeps refusing to admit he is indeed this Russian professor. In the following example, his preteritio is very telling: "the name Zembla is a corruption not of the Russian zemlya, but of Semblerland, a land of reflections, of 'resemblers"' (Nabokov 1962, 630). He refuses to acknowledge that he comes from a Russian land (zemlya) but insists on deceptive appearances when he conjures up the French verb "sembler" or the English noun "resemblers". Zembla is yet another portmanteau word mixing Russian and a European language.

For the slavist Laurence Guy, the Zemblan tongue is a trace of Botkin's painful exile: “Ce dépaysement linguistique est l'expression la plus forte de l'exil, et la solitude qui en résulte sa plus douloureuse conséquence" (Guy 2007, 216). Kinbote is actually a Russian exile who cannot cope with the loss of his native land and who resorts to creating a new idealized land. But he also creates the language that goes with it and every word in Shade's poem is therefore used by Kinbote as a pretext to talk about his native country. Thus, the word "iridule" is a springboard for the commentator who feels compelled to translate this poetic word into Zemblan: "An iridescent cloudlet, Zemblan muderperlwelk. The term 'iridule' is, I believe, Shade's own invention" (Nabokov 1962, 519). Once again, this forged language is hybridized and evokes the German word mutter (mother), the German or French perle (pearl) and wolke (cloud). Next to the German cloud (welk), it is the English expression "mother of 
FROM NABOKOV'S AMERUSSIA TO MALLARMÉ's DONJE TE ZANKORIV:

VLADIMIR NABOKOV AT THE CROSSROADS OF LANGUAGES

pearl" which seems to be hiding, in German and behind Kinbote's translation into English, "irisdescent cloudlet".

The Zemblan language keeps emerging in the text as a sign of Kinbote's painful exile because Zemblan words are ways of conjuring up the native land, even if it is an invented one, which thus continues to exist for him. This invented language becomes the symptom of the madness of a repressed Russian who feels the obsessive need to speak a tongue that only reveals his madness.

\section{The return of the repressed through Zemblan}

Zemblan, this language of the repressed, sometimes reveals the deceptive lie in Kinbote's story. For example, all along his commentary, Kinbote insists that Shade was killed by one of the many killers who wanted to kill the exiled king. However, in the following passage, the Zemblan word makes the reader pay attention and look for the concealed truth, which is that the killer was an angry man who was sent to jail by the judge who lent his house to Kinbote while he was away:

He did not bring up, my sweet old friend never did, ridiculous stories about the terrifying shadows that Judge Goldsworth's gown threw across the underworld, or about this or that beast lying in prison and positively dying of raghdirst (thirst for revenge) - crass banalities circulated by the scurrilous and the heartless - by all those for whom romance, remoteness, sealskin-lined scarlet skies, the darkening dunes of a fabulous kingdom, simply do not exist. But enough of this. (Nabokov 1962, 495)

Kinbote keeps insisting that Shade was not killed by a runaway prisoner: not only does he feel the urge to double his negations ("he did not bring up, my sweet old friend never did"), but he also rejects the rumours of convicts wanting to kill the judge between dashes and calls them "crass banalities". However, the Zemblan word in italics draws the reader's attention on its translation, given between brackets: "raghdirst (thirst for revenge)"; moreover, the very strange proximity between the two elements of the Zemblan word and their translation (thirst / dirst, revenge / ragh) points at the fabricated nature of this invented tongue.

Therefore, even though Kinbote cannot admit consciously that Shade's murder has nothing to do with him and that he is deluded when he pretends to be a king, it is the use of his invented tongue, Zemblan, which voices the truth he has repressed: he is not a king, and Shade was killed in an accident. Repression occurs when two demands of the ego are 
incompatible (for example, Kinbote's assertion of his status as a king and his knowledge of the truth):

In the course of things it happens again and again that individual instincts turn out to be incompatible in their aims or demands with the remaining ones, which are able to combine into the inclusive unity of the ego. The former are then split off from this unity by the process of repression, held back at lower levels of psychical development and cut off, to begin with, from the possibility of satisfaction. (Freud 1920,11)

Once again, the repressed returns through Kinbote's language. Another example of the forged nature of this language, but also of Kinbote's deception, is to be found when Kinbote recounts an episode in which he got drunk because he was not invited to Shade's birthday, whereas he keeps claiming they were best friends. Kinbote refuses to admit that Shade only saw him as an eccentric neighbour and that their friendship was all a figment of his mad imagination:

I still hoped there had been a mistake, and Shade would telephone. It was a bitter wait, and the only effect that the bottle of champagne I drank all alone now at this window, now at that, had on me was a bad crapula (hangover). (Nabokov 1962, 552)

The Zemblan word "crapula" is suspiciously close to the rare English word "crapulous" (characterized by gross excess in drinking). It is dubious that a foreign word should be so close to the English, be it in its pronunciation or in its meaning ("crapula" translated as "hangover"). But what is even more striking is the French echo to this Zemblan word: "crapule" (the French word for "crook") underlines Kinbote's deception as a supposed friend of Shade's and as a serious commentator of poetry. Kinbote himself often demonstrates his mastery of French in the novel and it thus appears that, through a hybridized English-French word, he shows once again that he cannot stop the linguistic return of the repressed and cannot master his own language.

\section{Kinbote's glossolalia}

Kinbote just cannot help but speak Zemblan when he is given a chance. This glossolalia shows he is unable to master his own language: he cannot refrain from linguistically conjuring up the country where he comes from. This phenomenon is particularly clear in the note that Kinbote writes in his commentary to explain Shade's use of the words "two 
FROM NABOKOV'S AMERUSSIA TO MALLARMÉ's DONJE TE ZANKORIV:

VLADIMIR NABOKOV AT THE CROSSROADS OF LANGUAGES

tongues". He cannot keep a profusion of languages from invading his writing:

(Line 615: two tongues)

English and Zemblan, English and Russian, English and Lettish, English and Estonian, English and Lithuanian, English and Russian, English and Ukrainian, English and Polish, English and Czech, English and Russian, English and Hungarian, English and Rumanian, English and Albanian, English and Bulgarian, English and Serbo-Croatian, English and Russian, American and European. (Nabokov 1962, 608)

All the pairs revolve around English (or American in the last case), which reminds us that America is now Kinbote's adopted country. But the most prevailing pair is "English-Russian": it is used four times as such but it is also disguised in other linguistic pairs since English is almost always coupled with other Slavic tongues, for example Lettish, Estonian or Ukrainian. Here, Kinbote's glossolalia is not expressed in Zemblan but the return of the linguistically repressed insists on Kinbote's true identity: he is Russian and American but he cannot cope with the loss of his roots.

\section{Conclusion}

Even though code-mixing is not found as often as code-switching in Nabokov's novels, these two ways of associating several languages are used with the same functions. In some previous research, I have found five central functions for foreign (or invented) words: effet de reel (in Barthes's sense), recreational, connotative, revealing and symptomatic.

1/ Illustrative function, or effet de réel: a foreign word can be used to ascertain the reality of the foreign country, be it real or imaginary, and it helps anchor the text in a linguistic reality as well as give it "couleur locale". Thus, in Ada, Bend Sinister or Pale Fire, the linguistic blends often illustrate a fictional country that mixes two or more countries we know: Amerussia in Ada or Russo-German vernacular in Bend Sinister. 2/ Recreational function: code-mixing or code-switching encourage the reader to decipher the text, be it for sexual innuendos or for poetic allusions: this was especially obvious in the macaronic languages in Lolita and Ada, but the vernacular in Bend Sinister also revealed that the power of suggestion inherent to a foreign tongue can be used in political ways. 
3/ Connotative function: in Nabokov's novels, foreign languages are often used for the connotations they bear with them (for example, French as the language of sexuality) and thus they convey or reinforce a message which is already present in the plot. This was the case for the connotations that are associated with German and Russian in Bend Sinister.

4/ Revealing function: code-mixing as well as code-switching help reveal how the plot will unravel, as deciphering the vernacular showed in Bend Sinister.

5/ Both linguistic associations can serve a symptomatic function, such as when Zemblan hints at the character's madness in Kinbote's case.

In this last case specifically, it is worth noting that, in his novels, Nabokov playfully endows his bilingual characters with pathologies, be they mental (madness in Pale Fire) or sexual (pedophilia and incest for example, as in Lolita). Other bilingual writers have embraced this cliché that bilingualism was a kind of disease: Todorov mentioned his bilingual schizophrenia (Todorov, 1985) and Triolet described herself as a bigamist (Beaujour 1989, 41). As for Federman, he claimed he suffered from all those pathologies at once (Federman 1993, 77):

I do not normally question or analyze my schizophrenic bilingualism. I just let it be, let it happen in me and outside of me. I have no idea in which side of my brain each language is located. I have a vague feeling that the two languages in me fornicate in the same cell. But since you are probing into my ambivalent (my ambidexterous) psyche, I can tell you that I believe I am lefthanded in French and righthanded in English. I am not kidding.

In all of his novels written in English, Nabokov demonstrated his bilingualism with code-switching and code-mixing, and he also chose to make his main characters polyglot, but also deviant. Nabokov despised psychoanalysis but he seemed to encourage the reader to look for signs of his own pathologies and deviances in his bilingual prose: his style is at the crossroads of languages and he entices the reader-decipherer to play catand-mouse with him to see what can be found behind his linguistic prowess. 


\section{BIBLIOGRAPHY}

BEAUJOUR, Elizabeth Klosty. 1989. Alien Tongues: Bilingual Russian Writers of the "First" Emigration. Ithaca : Cornell University Press.

COUTURIER, Maurice. 1993. Nabokov ou la Tyrannie de l'auteur. Paris : Seuil.

DHARWADKER, Vinay. 2011. "Diaspora and cosmopolitanism." In M. ROVISCO and M. NOWICKA (eds), The Ashgate Research Companion to Cosmopolitanism. Farnham, Great Britain: Ashgate, p. $125-144$.

FEDERMAN, Raymond. 1993. “A voice within a voice.” Critifiction: Postmodern Essays. Albany: State University of New York Press, p. 77-84.

FREUD, Sigmund. 1920. Beyond the Pleasure Principle. Standard Edition, vol. XVIII. London: Hogarth.

GARAVINI, Fausta. 1982. "Étude critique et genre macaronique." Bulletin de l'Association d'étude sur l'humanisme, la réforme et la renaissance $15: 40-47$.

GLISSANT, Édouard. 1990. Poétique de la relation. Paris : Gallimard.

GUY, Laurence. 2007. Vladimir Nabokov et son ombre russe. Aix-enProvence : Publications de l'Université de Provence.

NABOKOV, Vladimir. 1996 [1947]. Bend Sinister. In B. BOYD (ed.), Nabokov, Novels and Memoirs, 1941-1951. New York: Library of America, p. 161-358. 
NABOKOV, Vladimir. 1996 [1955]. Lolita. In B. BOYD (ed.), Nabokov, Novels, 1955-1962. New York: Library of America, p. 1-298.

NABOKOV, Vladimir. 1996 [1962]. Pale Fire. In B. BOYD (ed.), Nabokov, Novels, Novels, 1955-1962. New York: Library of America, p. 437-667.

NABOKOV, Vladimir. 1996 [1969]. Ada or Ardor: A Family Chronicle. In B. BOYD (ed.), Nabokov, Novels, 1969-1974. New York: Library of America, p. 1-485.

NABOKOV, Vladimir. 1975. Ada ou l'Ardeur. G. Chahine and J.-B. Blandenier (trans.). Paris : Fayard.

SORLIN, Sandrine. 2010. La Défamiliarisation linguistique dans le roman anglais contemporain. Montpellier : Presses universitaires de la Méditerranée.

TODOROV, Tzvetan. 1985. "Bilinguisme, dialogisme et schizophrénie." In J. BENNANI et al (eds), Du Bilinguisme. Paris : Denoël, p. 11-38 